\title{
Pathophysiology, Causes and Treatment of Chronic Cough in Adults: Literature Review
}

\author{
Heejin $\mathrm{Kim}^{1}$ and Myung-Whun Sung ${ }^{2}$ \\ ${ }^{1}$ Department of Otorhinolaryngology, Kyungpook National University College of Medicine, Daegu; and \\ ${ }^{2}$ Department of Otorhinolaryngology, Seoul National University College of Medicine, Seoul, Korea
}

\section{성인의 만성 기침의 병태 생리 및 원인과 치료: 문헌 고찰}

\author{
김 희 진 ${ }^{1} \cdot$ 성 명 훈 $^{2}$ \\ 경북대학교 의과대학 이비인후과학교실, ${ }^{1}$ 서울대학교 의과대학 이비인후과학교실 ${ }^{2}$
}

\author{
Received September 1, 2014 \\ Accepted June 23, 2015 \\ Address for correspondence \\ Myung-Whun Sung, MD, PhD \\ Department of Otorhinolaryngology, \\ Seoul National University \\ College of Medicine, \\ 101 Daehak-ro, Jongno-gu, \\ Seoul 03080, Korea \\ Tel $+82-2-2072-3830$ \\ Fax $+82-2-745-2387$
}

E-mail mwsung@snu.ac.kr
Chronic cough is a common symptom and the etiology of which can be challenging to diagnose. The key to successful management is to establish a diagnosis and to treat the cause of cough. Asthma, gastro-esophageal reflux, and postnasal drip syndrome have been thought to be most common causes of chronic cough. Various causes such as lung diseases (sarcoidosis, pertussis), obstructive sleep apnea, drug (angiotensin-converting enzyme inhibitor), and psychological status can induce chronic cough. However, many chronic cough patients do not have an identifiable cause. We need to understand the mechanisms underlying central and peripheral sensitization, how they interact with cough triggers and their relationship with the sensations that drive the urge to cough, and the subsequent motor cough response in chronic cough. Heightened cough reflex sensitivity is persistent and their cough is unexplained in many patients. In most patients who visited otorhinolaryngoloy clinics, it is possible to manage a majority of chronic cough patients successfully using a protocol based on presenting symptoms and therapeutic trials for the common causes of cough. However, there are few therapeutic options for patients with unexplained chronic cough. There is a pressing need to understand the physiological basis of unexplained chronic cough and to develop novel antitussive drugs that down regulate cough reflex sensitivity. Korean J Otorhinolaryngol-Head Neck Surg 2015;58(11):744-53

Key Words Antitussive agents · Cough · Gastroesophageal reflux · Physiopathology · Respiratory hypersensitivity.

\section{서 론}

기침은 감기, 천식, 몸살, 재채기, 객담 등의 여러 표현과 혼 동되어 사용될 수 있는 증상으로, 성인의 기침 증상은 그 지속 기간에 따라 급성(3주 이내), 아급성(3 8주), 만성(8주 이상) 으로 나눌 수 있다. 일반적으로 증상이 3주 이상 지속되는 경 우에 만성 기침이라고 하며, 전 인구의 3 40\%에 달하는 매 우 흔한 질환이다. 기침은 조절할 수 있는 수의적 기침과 기도 를 보호하기 위해 불수의적으로 일어나는 반사적 기침으로 나눌 수 있다. 반사적 기침이 일어나는 기전에 대해서는 미주
신경이 관여한다는 것은 널리 밝혀진 바 있으나, 수의적 기침 을 조절하는 것에 대해서는 여러 복잡한 기전이 작용할 것으 로 보인다. 정상적으로 기침은 기도나 폐를 보호하기 위해 일 어나는 중요한 역할을 하지만, 천식이나 폐쇄성 폐질환, 역류 성 식도질환 혹은 후비루와 같은 상기도 질환 등의 질병이 있을 때에도 발생할 수 있다.

만성 기침을 성공적으로 치료하기 위해 중요한 것은 적절한 진단을 내리고 그 원인을 치료하는 것으로, 기존의 가이드라 인에서는 세 가지 가장 흔한 유발 요인[천식, 위식도 역류질환 (gastroesophageal reflux disease, GERD), 후비루(postnasal 
drip, PND) 증후군]의 여부에 대해 먼저 살펴볼 것을 권고하 고 있다. ${ }^{1-3)}$ 이전 연구에 따르면, 이 세 가지 원인에 알맞은 치 료만으로도 $98 \%$ 이상에서 증상 호전을 보였다.) 실제로 원 인이 없이 발생하는 기침은 매우 드물지만 기관지 외의 다른 원인에 의해 유발되는 기침의 경우 그 원인을 알아내기 어려 운 경우가 종종 있으며, 이를 특발성 기침(idiopathic cough)보 다는 설명되지 않는 기침(unexplained cough)으로 부른다. ${ }^{5)}$ 질병 이외의 환경적 요인으로 흡연은 기침과 많은 관련성을 보인다고 하지만 실제 환자 중 흡연으로 인한 기침으로 내원 하는 사람은 극히 드물며, 다수의 만성 기침 환자들은 여성이 다. 성별에 따른 기침의 반응 차이에 대해, 여성이 내재적으로 기침에 대한 반응이 상향되어 있는 것으로 보이며,5, angiotensin-converting enzyme(ACE) 억제제로 인한 기침 반응 도 더 높다는 보고가 있지만 ${ }^{7)}$ 그러한 차이에 대한 원인은 아 직 밝혀지지 않았다. 따라서 기침 반응의 과민성(cough reflex sensitivity)의 변화가 만성 기침을 설명할 수 있는 중요한 기 전의 개념으로 생각할 수 있으나, 아직까지 그 기전과 치료에 대해서는 알려진 바가 적다.

본 논고에서는 매우 빈번하게 발생하는 성인의 만성 기침과 관련된 전반적인 내용을 문헌 고찰함으로써, 이비인후과 의 사로서 만성 기침의 원인을 분석하고 효과적으로 치료하는 데 일조하고자 한다.

\section{본 론}

\section{기침 발생의 기전}

기침은 대뇌와 소뇌의 작용으로 발생하며, 공기를 깊게 들 여 마시는 흡기, 성대를 닫은 상태에서 횡경막을 이완시키고 흉곽 근육을 수축시켜 기도 압력을 높이게 되는 압축기, 그 리고 기관지가 좁아지면서 성대가 열리고 강한 힘의 공기가 이 물 및 점액과 함께 빠져나오는 호기로 이루어진다. 이때 공기 흐름의 속도는 시속 약 $150 \mathrm{~km}$ 까지도 다다르며, 이는 미국 프로야구에서 투수가 던진 공의 속도보다 빠르다.

\section{기침 발생의 신경생리학적 기전}

기침은 자발적으로 일어날 수 있기도 하지만, 기침 반응은 감각과 운동 신경의 복잡한 상호 작용에 의해 나타난다(Figs. 1 and 2). 기침 반응은 상기도의 자극이 감각 수용체를 흥분 시켜 발생한 수용성 정보를 감각 신경을 통해 뇌간으로 보 내, 뇌와 뇌간의 운동 신경으로 정보가 전달되어 늑간 근육이 나 횡경막의 움직임을 일으켜 발생한다.

기도에는 세 가지 이상의 미주신경을 통하는 구심성 신경이 분포하는 것으로 생각되는데, ${ }^{8-10)}$ 각기 다른 자극에 다른 방식

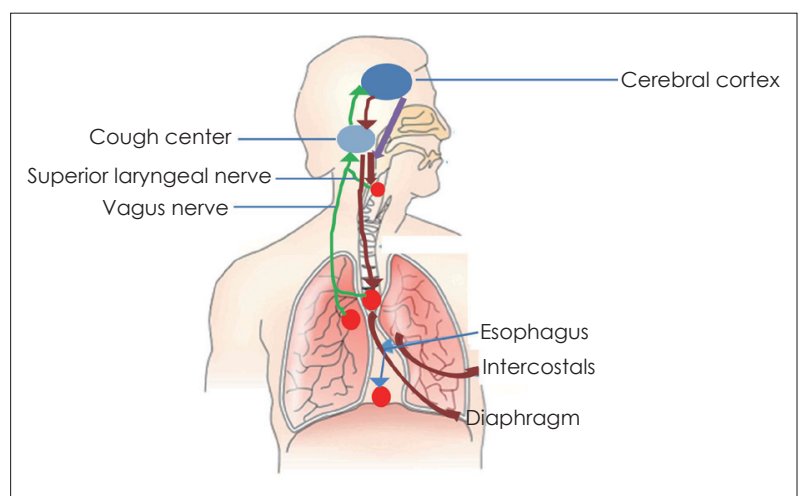

Fig. 1. Anatomical representation of neural pathways for cough. Cough receptors (shown in red color) at the airway bifurcations, in the larynx, and at the distal esophagus, link to cough afferents through the vagus and superior laryngeal nerves to the cough center and cerebral cortex. Efferent pathways coordinate the muscle response that leads to a cough.

으로 반응한다. 주로 기계적 자극에 반응하는 rapidly adapting receptors(RARs)와 slowly adapting receptors, 그리고 캡사이신과 같은 화학적 자극에 주로 반응하는 C-fibers로 대별된다(Table 1). ${ }^{8}$ 기침에 관여하는 C-fiber(unmyelinated postganglionic fibers of the autonomic nervous system)는 기관지와 폐에 존재하는 C-fiber로 나뉘며 이들은 각각 경정 맥신경절(jugular ganglia)과 결절 신경절(nodose ganglia)에 서 기원한다. ${ }^{8)} \mathrm{C}$-fiber 수용체에서는 substance P, neurokinin $\mathrm{A}$, calcitonin gene-related peptide 등과 같은 neuropeptide 를 분비하는데, 이러한 neuropeptide들은 혈관의 확장, 상피 세포의 손상, 점막 하 샘의 분비, 감각 수용체 자극 등과 같은 neurogenic inflammation을 일으켜 RARs로 하여금 기침 반 응을 일으키도록 한다. Tachykinin은 이러한 neuropeptide의 일종으로, 고혈압 치료제로 쓰이는 ACE 억제제가 tachykinin 과 bradykinin의 분해를 막기 때문에 ACE 억제제를 사용하 는 약 $10 \%$ 의 환자에서 약제에 의한 기침이 발생할 수도 있 다. C-fiber는 RARs 혹은 다른 수용성 신경과 뇌간에 존재 하는 고립로핵(nucleus tractus solitarius)에서 기침 반응을 중재하는 데 함께 작용하여 상승 작용을 일으키기도 한다. 한편 C-fiber는 마취에 의해 억제되며,10) 전신 마취 하에서 C-fiber가 활성화 되면 RARs에 의해 일어나는 기침 반응이 억제되므로 뇌간과 대뇌 피질과의 잠재적인 경로가 있을 것 으로 생각되나, 아직 밝혀진 바는 적다(Fig. 3). 그러한 이유로 미주신경절단술 혹은 부분마취제를 이용한 미주신경 차단 은 기침을 억제하지만, ${ }^{11}$ 경추 손상을 받은 환자들에게서는 기침 반사가 보존된다. ${ }^{12)}$

C-fiber는 말초 부분에 존재하는 transient receptor potential vanilloid 1(TRPV1)과 같은 ligand-gated ion channel 의 일종에 의해 활성화되며, 이는 $42 ~ 53^{\circ} \mathrm{C}$ 의 고열, 낮은 $\mathrm{pH}$, 


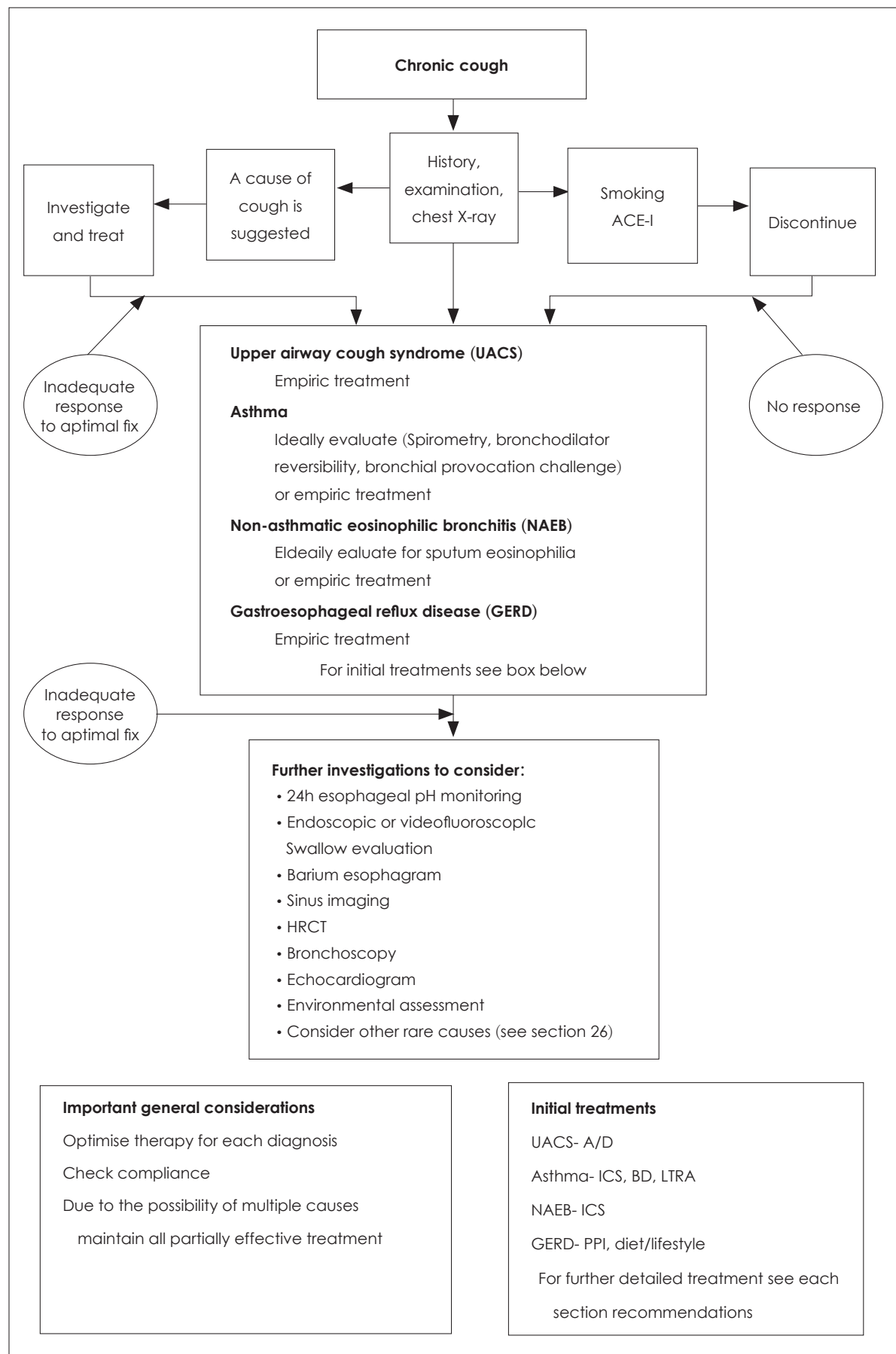

Fig. 2. Clinical guideline of chronic cough (ACCP evidence-based clinical practice guidelines, 2006). ACEI: angiotensin-converting-enzyme inhibitor, HRCT: high resolution computed tomography, A/D: antihistamine/decongestant, ICS: inhaled corticosteroids, BD: bronchodilator, LTRA: leukotriene receptor antagonist, PPI: proton pump inhibitor.
캡사이신 등과 같은 자극에 반응한다. 한 연구에서 만성 기 침이 있는 환자의 기관지 조직 검사를 시행하여 TRPV1 수 용체의 발현이 증가되어 있음을 발견하여 기침과 TRPV1 수 용체와의 상관관계를 밝혀낸 바 있다. ${ }^{13)}$ 임상적으로 흔히 사 용되는 theobromine은 C-fiber 및 RARs의 말초 부분에 존 재하는 TRPV1 수용체의 길항제로, 기관지 수축을 억제하고 확장시키는 효과 및 점액섬모운동을 향상시켜 객담이 많은 환자에게도 진해제로 사용할 수 있다. 반면 codeine은 중추성
으로 작용하여 기침을 억제하나 호흡 기능 및 기관지 섬모운 동 또한 억제하여 객담 배출을 방해하므로 객담이 많은 환자 에게는 사용하기 어렵다.

한편 폐나 기관지 외의 다른 장기가 기침의 발생에 연관을 보이기도 하는데, 귀를 건드리면 기침이 발생하거나(Arnold reflex), 인두에 기계적인 자극, 후비루 혹은 한꺼번에 물이 많이 넘어가게 될 때 미주신경, 혀인두신경, 삼차신경의 작용 에 의해 극심한 기침이 발생하기도 한다. 하지만 흥미로운 것 
Table 1. Properties of vagal afferent nerve subtypes innervating the airways (modified from Canning et al., 2009)

\begin{tabular}{|c|c|c|c|}
\hline Properties & RARs & SARs & C-fibers \\
\hline \multicolumn{4}{|l|}{ Electrophysiologic } \\
\hline Conduction velocity, $\mathrm{m} / \mathrm{s}$ & $14-23$ & $15-32$ & $0.8-1.5$ \\
\hline Myelination & Yes & Yes & No \\
\hline Eupneic activity, impulses/s & $0-20$ & $10-40$ & $0.3-1.5$ \\
\hline \multicolumn{4}{|l|}{ Morphologic } \\
\hline Neuropeptide synthesis & No & No & Yes \\
\hline Innervation of large airways ${ }^{\dagger}$ & Yes & Sparse & Yes \\
\hline Innervation of small airways & Yes & Yes & Yes \\
\hline \multicolumn{4}{|l|}{ Physical sensitivity } \\
\hline Mechanical threshold & Low & Low & High \\
\hline Lung deflation* & Activated & Inactivated & No effect \\
\hline Edema & Increased & No effect & Increased \\
\hline \multicolumn{4}{|l|}{ Chemical sensitivity* } \\
\hline $\mathrm{CO}_{2}$ & No effect & Decreased & Increased \\
\hline $\mathrm{H}^{+}$ & Increased & No effect & Increased \\
\hline Capsaicin* & Increased ${ }^{\dagger}$ & No effect & Increased $\ddagger$ \\
\hline Bradykinin* & Increased ${ }^{\dagger}$ & No effect & Increased $\ddagger$ \\
\hline \multicolumn{4}{|l|}{ Reflex effects } \\
\hline Parasympathetic & Excitatory & Inhibitory & Excitatory \\
\hline Respiratory & Hyperpnea & Inhibit inspiration & Apnea \\
\hline Axon reflex & No & No & Yes \\
\hline
\end{tabular}

*typical attributes of the afferent nerve subtypes are listed. Species differences and subtypes of each class with distinct physiologic properties and responsiveness have been reported, the activation of RARs by capsaicin and bradykinin is prevented by bronchodilator pretreatment, suggesting that activation occurs secondary to obstruction in the lung, 抽-fiber activation by bradykinin and capsaicin is enhanced by bronchodilators such as adrenaline, adenosine, and prostaglandin E, suggesting that agents directly stimulate C-fibers in the airways. See text for further details and references. RARs: rapidly adapting receptors, SARs: slowly adapting receptors

은, 인두에서는 캡사이신과 같은 자극이 기침을 발생시키지 않는다는 것이다. 또한 식도에서 기침을 유발하는 기전에 대 해서는 위식도 역류와의 관련성이 강하게 의심이 되지만, 실 험적으로 증명된 바는 없다. 또한 위약을 이용한 진해 효과 에 대한 보고를 통해 심리적인 요인에 의한 기침 발생의 가 능성도 고려할 수 있다. ${ }^{8)}$

만성 기침 환자의 신경생리학적 측면-감작(sensitization)

만성 기침 환자들은 정상인에 비해 기침 반응이 더 과민하 게 나타나는 경향을 보이며, 이는 감작의 측면으로 설명할 수 있다. 기침하려는 충동은 보통 억제할 수 있으며, 캡사이 신 기침 유발 검사에서 보통 사람의 경우 기침 충동 시에 6배 이상의 용량까지 억누를 수 있는 데 비해, 만성 기침이 있는 환 자들에서는 2 배가량의 용량밖에 억제하지 못한다. ${ }^{14)}$ 중추성 감작은 말초 신경의 자극에 대해 중추신경계의 반응이 향상 된 것으로, 만성 기침 환자들이 향수나 찬 공기 등과 같은 작 은 자극원에 대해서 과도하게 기침을 하게 되는데, 이는 중 추성 혹은 말초성 감작에 의해 기침을 유발하는 자극에 대 한 역치가 낮아졌기 때문이다. 그러나 어떤 환자들은 전화
통화를 하거나 웃거나 노래를 하는 것과 같은 자극에 대해서 도 기침을 하기도 하며, 이러한 자극들은 기침을 유발하기에 충분하지 않지만 이러한 감각 정보에 반응하는 중추신경의 방식이 바뀐 것을 의미한다. 이는 통증의 측면에서, 상처 부위 근처에서 무해한 자극에 반응하는 통증과 같은 것으로, 중 추 감작에 의한 것이다. 내장 신경계 또한 뇌간에서 감각 신 경이 수렴하기 때문에 식도와 같은 폐 외 부위에서 기침이 유 발되는 이유를 내장 과민성으로 설명할 수 있다. 이러한 중 추신경계의 상향조절은 감각 자극이 오래될수록 영구적이 될 수 있으며, 중추 감작된 환자들에게 중추에 작용하는 neurokinin 길항제가 진해 작용을 한다.

한편 말초신경 과민성의 상향조절은 화상 입은 곳을 만지 는 것과 같은 국소적인 요인에 의해 발생한다. 한 연구에 따르 면 만성 기침 환자에서는 정상인에 비해 기도 내 염증 매개자 (histamine, prostaglandin D2, prostaglandin E2)의 수치가 증가되어 있다고 한다. ${ }^{15)}$ 염증 매개자들은 $\mathrm{G}$-protein coupled receptor에 부착하여 말초 미주신경 말단을 감작시켜, 다양한 세포 내 과정을 거쳐 action potential을 시작하는 역치를 낮 춘다. 이러한 현상은 이전 연구에서 prostaglandin E2를 흡인 
Fig. 3. Potential actions of and interactions between the vagal afferent nerves mediating cough. Excitatory pathways regulating cough are highlighted in blue. Inhibitory pathways regulating cough are highlighted in red (modified from Canning, 2006). NTS: nucleus tractus solitarius, TRPV1: transient receptor potential vanilloid 1, GABA: gamma-aminobutytic acid, PDE: phosphodiesterase, CB2 receptor: cannabinoid receptor type 2 .

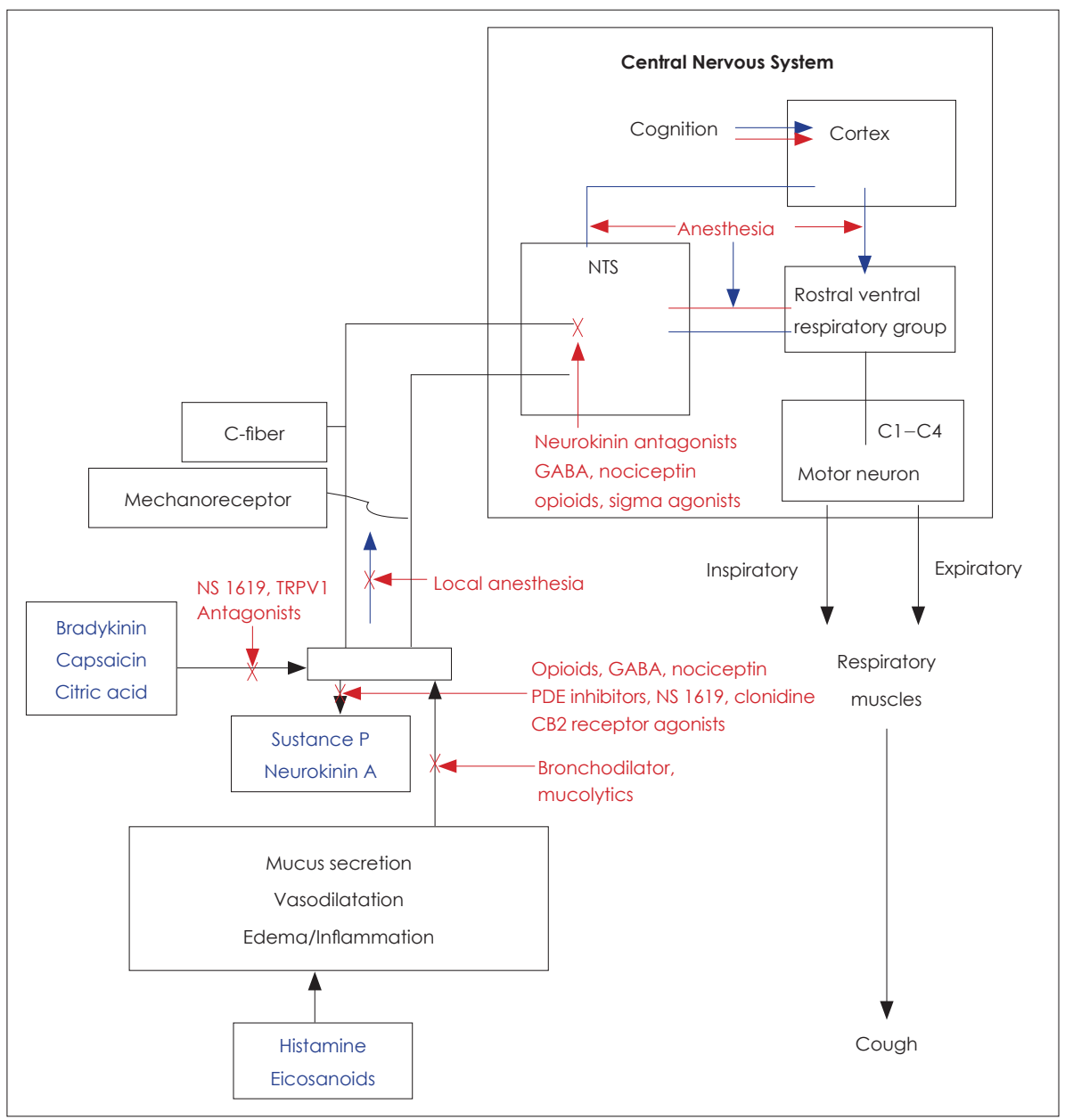

한 후 캡사이신을 흡인하면 기침 반응이 증가함을 관찰함으 로써 확인할 수 있다.

\section{만성 기침의 원인}

만성 기침을 호소하는 전형적인 성인 환자는 폐경 후 여성 으로, 5 년 이상의 기침 병력이 있으며 온도 변화 혹은 화학 스 프레이 등과 같은 자극 요인에 반응하여 악화된다. 하지만 먹 거나 고개를 특정한 부위로 돌리는 것과 같은 일상 활동에 대해서도 기침을 일으키기도 한다. 항우울제를 복용하거나 사회적으로 고립되어 있기도 하고 여러 치료를 시행하였으나 호전을 보이지 않기도 하며, 항상 물을 가지고 다니고 본인의 불편함을 써서 가지고 다니기도 한다. 특정한 환경적 요인이 없고 비흡연자이며, 흥부 단순촬영에서 정상 소견을 보이며, $\mathrm{ACE}$ 억제제를 복용하지 않는다. 이러한 만성 기침 환자의 $86 \%$ 는 후비루, 천식, 그리고 GERD와 관련이 있다고 하며 (Table 2), 만약 ACE 억제제를 사용한 적이 없으며 흥부 단 순촬영 소견이 정상인 비흡연자를 대상으로 할 때 이 확률 은 $99 \%$ 까지 증가한다. ${ }^{4)}$ 그러므로 만성 기침으로 병원을 찾
는 건강한 성인의 대다수의 진단은 제한되어 있다. 이들 중 알레르기 반응이 음성이며, 부비동 검사나, 폐기능 검사가 정상 인 경우는 거의 모두 GERD와 관련이 있다고 볼 수 있으며, 실제 GERD와 관련된 기침은 $40 \%$ 를 넘는다고 한다. ${ }^{16)}$

\section{위식도 역류(GERD)와 만성 기침}

$\mathrm{GERD}$ 는 기침의 가장 흔한 원인으로 알려져 있으며, 산의 역류로 인해 기침이 발생하고 기침을 함으로써 복압이 올라가 산의 역류를 일으키는 악순환이 발생하게 된다. $40 \%$ 의 환자 들은 속쓰림 등과 같은 GERD의 증상이 나타나지 않는 "조 용한 역류” 현상을 나타내며, 이는 아주 짧은 기간 동안 산이 역류되는 현상에 의해 일어날 수 있으며 이러한 경우에는 24 $\mathrm{hr} \mathrm{pH}$ monitoring을 통해서도 발견이 되지 않을 수 있다. 하 지만 역류의 증거가 없거나 기관지 내시경 상으로 다른 이상 의 소견이 없는 환자의 일부에서 역류를 억제하는 약물 치료 만으로 기침 증상의 호전을 보이는 경우가 있다. ${ }^{17)} \mathrm{GERD}$ 와 관 련하여 기침이 발생하는 기전에는 두 가지 가설이 알려져 있 다. 첫 번째는 하부 식도로 산이 노출되어 미주신경을 통해 
Table 2. Differential diagnosis for cough in adults

\begin{tabular}{ll}
\hline PND & Psychogenic \\
Allergic rhinitis & Chronic aspiration \\
Chronic sinusitis & Zenker's diverticulum \\
GERD/LPR & Foreign body \\
Cough-variant asthma & Tracheobronchial tree \\
ACE inhibitor medications & Laryngopharynx \\
Pertussis (whooping cough) & Sinonasal \\
Neurogenic & External auditory canal \\
Traumatic vagal injury & Chronic bronchitis \\
Post-URI neuropathy & Subglottic stenosis \\
Bronchiectasis & Tracheomalacia \\
Lung carcinoma & Tuberculosis \\
Tracheoesophageal fistula & Congestive heart failure \\
Sarcoidosis &
\end{tabular}

PND: posterior nasal drip, GERD: gastroesophageal reflux disease, LPR: laryngopharyngeal reflux, URI: upper respiratory infection

기관-식도의 기침 반응을 자극하는 것과, 두 번째로 인후두 와 기관-기관지로 식도의 내용물이 미세 흡인되는 것이다. 첫 번째 기전은 전형적인 GERD와 함께 발생하나 두 번째 기 전은 식도 외 역류나 인후두 역류에 의해 발생한다. Irwin 등 ${ }^{18)}$ 이 dual-channel pH monitoring을 통해 하부 식도에 산이 노출되는 것이 상부에 비해 기침의 발생과 관련이 있음을 밝 혀낸 바 있으며, 다른 연구에서는 기침이 하부 식도에 식염수 를 주입하였을 때에 비해 산이 있을 때 확연하게 증가함을 보고하였다. ${ }^{19)}$ 위식도 역류가 일어나는 원인으로 가장 중요한 것은 하부식도 조임근의 역할로, theophylline, progesterone, alpha-adrenergic antagonist, beta-adrenergic antagonist, calcium channel blocker, nitrates 등과 같은 약제는 하부식 도 조임근의 긴장도를 낮추는 역할을 하므로 투약력을 살펴 볼 필요가 있다.

치료를 위해 중요한 것은 생활 습관의 교정으로, 흡연 및 음주, 고지방 및 고단백의 음식, 카페인이 함유된 음식의 섭 취를 줄이는 것이다. 가장 중요한 것은 체중을 줄이고, 잠들 기 3 시간 전에 음식을 섭취하는 것을 금하며 침대 머리를 높 이는 것을 권고하고 있다. 투약으로는 proton pump inhibitor (PPI) 및 prokinetic therapy 등을 처방한다. 하지만 어떤 연구 에서 위식도 역류와 관련된 만성 기침이 PPI 치료에 반응을 보이지 않는 결과들이 발표된 바 있었으며, ${ }^{20)}$ 이에 따라 산 이 외의 bile 등과 같은 다른 물질의 역류에 의한 기침의 가능성 도 제기되고 있다.

\section{기침성 천식}

천식은 염증으로 인하여 다양한 기도의 폐쇄를 포함하는
호흡기 질환이다. 천식은 숨이 짧아지고 천명이 주된 증상이 며 밤에 심해지는 경향을 보일 수 있으나, 기침성 천식(coughvariant asthma, $\mathrm{CVA}$ )의 경우 종종 이러한 천식 증상이 나 타나지 않기도 한다. 천식을 진단하기 위해서는 폐기능 검사 를 사용하여 metacholine을 흡인 한 후 노력성 호기량이 1초 안에 적어도 $20 \%$ 이하로 감소하거나, 기관지확장제를 흡인 후 적어도 $15 \%$ 이상 좋아지는 지를 확인하여 진단한다. 하지 만 이러한 진단 기준은 간혹 기침성 천식에 맞지 않을 수 있 어 이러한 폐기능 검사 결과 없이 경험적으로 4 8주간 코르 티코스테로이드를 흡인하여 증상 변화를 보기도 하며, 때때 로 수개월간 지켜보면서 지연성 반응을 지켜보기도 한다. 스 테로이드 치료에 반응을 보이는 것은 비천식성 호산구성 기관 지염(nonasthmatic eosinophilic bronchitis, NAEB)과의 감 별이 필요하다. 흡인성 스테로이드와 기관지확장제에 반응을 보이지 않는 환자들에게, zafirlukast 등과 같은 leukotriene inhibitor를 추가하면 효과적일 수 있다는 보고가 있으며, 약 물에 반응하지 않는 심각한 환자들에게는 흡인성 스테로이 드와 함께 1 2주 동안 전신적인 스테로이드 투약을 시행하기 도 한다.

\section{호산구성 기관지염(NAEB)}

호산구성 기관지염의 개념은 1989 년에 $\mathrm{Gibson}^{7)}$ 에 의해 만 성 기침의 한 원인으로 처음 제기되었다. 이는 천식과 같은 기 관지의 기능 이상 없이도 비흡연자에게서 스테로이드에 반응 을 보이는 것으로, 특이적으로 객담에서 호산구가 관찰되어 그 이름이 붙여졌다. 원인은 정확히 밝혀진 바는 없지만 직업 적으로 감작되거나 자주 흡입하게 되는 항원과 연관되어 있 다고 생각된다. 진단을 위해서는, 천식과 관련된 기관지의 과 민성이 관찰되지 않고, 객담 혹은 기관지 세척액에서 $3 \%$ 이상 의 호산구가 관찰되어야 하며, 스테로이드 치료에 반응을 보 여야 하지만 확진을 위해서는 기관지 점막의 생검이 필요하 다. 호산구성 기관지염은 기침 반응의 과민성을 보이며 스테 로이드에 반응을 보인다는 점에서 기침성 천식과 유사하나, 기침과 함께 상기도 증상이 종종 동반되며 기도 과민성을 보 이지 않고 기관지확장제에 반응을 보이지 않는다는 점에서 기침성 천식과 감별할 수 있다.

치료는 원인이 되는 항원을 피하거나, 스테로이드 흡인으로 항염증 치료를 하는 것이 제 1 원칙이 될 수 있다. 치료를 하지 않고 두었을 때의 자연경과에 대한 연구는 별로 되어 있지 않으나, 52명을 대상으로 한 연구에서는 자연 관해되는 경우 가 거의 없으며, $66 \%$ 에서 질병이 진행되거나 증상이 지속되고, $16 \%$ 에서 기도의 변화를 보였다고 한다.) 


\section{후비루(PND); 상기도 기침 증후군}

후비루 증후군은 비강 내 점액이 인두를 통해 흘러 내려가 목 청소를 계속하게 하거나 불편감을 느끼게 하는 증상으로, 후비루 증후군에 의한 기침은 보통 환자의 병력이나 신체 검 진, 영상 소견, 그리고 치료에 대한 반응 정도를 통해 진단하 게 된다. 최근에는 후비루 증후군이라는 용어보다 상기도 기 침 증후군(upper airway cough syndrome, UACS)과 같은 용 어를 사용한다.

알레르기/비알레르기성 비염, 비강 내 폴립, 비부비동염 등 과 같은 소견에 의해 후비루가 나타날 수 있으나, 후비루 증 후군에 의해 만성 기침이 일어날 수 있는지에 대해서는 아직 논쟁 거리가 있다. 후비루와 관련되어 기침을 하는 환자의 약 $20 \%$ 에서 후비루를 못 느끼는 경우가 있기도 하며, ${ }^{21)}$ 반대로 실제 후비루가 있는 환자의 약 $21 \%$ 만이 기침 증상을 나타낸 다는 보고가 있다. ${ }^{22}$

UACS는 경험적인 치료를 일차적으로 하게 되는데, 이는 치 료에 대한 반응 여부가 UACS의 진단 방법 중 하나이기 때 문이다. 특정한 원인이 밝혀지지 않은 환자에게 경험적인 치 료로 1 세대 antihistamine과 비충혈제를 진단 검사를 하기 전 에 처방할 수 있다. 2, 3세대 antihistamine이나 비진정성 항 히스타민제는 기침을 억제하는 데 도움이 되지 않는다. 이러한 1 차적 투약에 호전되지 않은 환자에게 부비강 영상 검사 및 비 강 검사를 시행할 수 있다.

\section{$\mathrm{ACE}$ 억제제에 의해 유발되는 기침}

$\mathrm{ACE}$ 억제제를 복용하는 환자의 $1 / 3$ 에서 기침을 호소한다 고 알려져 있으며, 실제 보고에 의하면 약 $10 \%$ 에서 기침을 호소한다고 한다. ${ }^{23)} \mathrm{ACE}$ 억제제는 bradykinin과 substance $\mathrm{P}$ 와 같은 물질이 비활성화된 peptide로 분해되는 것을 억제 하여 prostaglandin, leukotriene, histamine과 같은 염증 매 개 물질의 생성을 높이고, 염증 매개 물질이 말초성 미주신경 의 말단이나 C-fiber의 수용체에 반응하여 기침 작용을 일 으킨다. $\mathrm{ACE}$ 억제제에 의한 기침은 치료 시작 후 수주 이내 에 일어날 수 있으나, 치료 시작 후 수개월이 지나거나 수년이 지난 후에 발생하는 것도 가능하다. 그러므로 투약을 한 기 간과 상관 없이 기침이 있을 때 약을 끊어 보는 것이 중요하 다. 만약 기침이 약에 의해 발생했다면, 약을 끊고 4주 이내 에 증상이 호전되거나 확연히 좋아질 것이다. $\mathrm{ACE}$ 억제제는 거의 모든 경우에서 같은 증상을 유발하므로, angiotensin II 억제제가 훌륭한 대체제가 될 수 있다. $\mathrm{ACE}$ 억제제를 끊 을 수 없는 상황이라면 기침에 대한 보조 치료가 필요하며 최 근 연구에 의하면 cromolyn sodium이나 hydrochlorothiazide 등이 $\mathrm{ACE}$ 억제제에 의한 기침의 개선에 도움이 된다고 한다. ${ }^{23)}$
백일해(Bordetella pertussis; whooping cough)

백일해는 지난 수십 년 동안 다시 증가하기 시작하면서 성 인의 만성 기침의 감별 진단으로 떠오르기 시작하였다. 대부 분의 어린이들은 백신을 맞게 되지만 면역력은 12살 이후부 터 줄어들기 시작한다. 지난 25년간 미국에서 백일해의 숫자 는 증가하기 시작하여 2001년에는 8000예 이상이 보고되었 다. 백일해는 콧물, 후비루, 목청소 등과 같은 비특징적인 상 기도 감염으로 시작되며 전형적으로 이러한 증상은 2주간 지속된다. 이러한 증상이 지나간 후에 기침이 발생하기 시작 하며, 심한 발작적인 기침으로 주저앉거나 구토를 하기도 한 다. 기침은 2 4주에서 수개월간 지속될 수 있으며 심한 기침 후에 역류 질환이 발생하여 기침이 지속될 수도 있다. 백일해 의 진단은 백일해를 배양하기 어렵기 때문에 진단이 어려우 며, 초기에 비인두 swab을 하여 polymerase chain reaction (PCR)을 이용하여 진단할 수 있으며, 후기에는 백일해에 대한 혈청 검사를 통해 진단할 수 있다. 마크로라이드 항생제는 접 촉자들에게 예방적으로 사용할 수 있으며 코데인이 대증적인 요법으로 사용될 수 있다.

\section{바이러스 감염 후 미주신경병증(Post-viral vagal} neuropathy)과 기침

바이러스성 감염을 않은 후 발생한 미주신경병증은 다른 여러 가능한 원인들을 배제한 후, 만성 기침의 잠재적인 원인 으로 고려할 수 있다. 선행한 바이러스성 상기도 감염에 의해 미주 신경분지가 손상을 받아 시작되었을 것으로 보이며, 신 경병증 이후 신경섬유의 재생이 비정상적으로 이루어지면서 성대 마비나 혹은 통증을 동반한 감각이나 운동신경 기능이 손상된다. 상기도 감염이 선행된 후 그 결과로 지속적인 미 주신경의 손상을 보이는 경우가 보고된 바 있었으며, ${ }^{24)}$ 이는 미주신경 말단의 무스카린 수용체인 M2 수용체의 손상에 의해 기도 과민 반응이 나타났을 것으로 생각된다. 기도 내 근 육에 존재하는 M3 수용체가 아세틸콜린과 반응하여 근육의 수축을 일으키는 반면, M2 수용체는 미주신경의 말단에 존 재하여 아세틸콜린의 음성 피드백 역할을 하여 아세틸콜린 의 분비를 억제하는 역할을 한다. 동물 실험에서 M2 수용체 의 길항제를 투여하여 기도수축 반응이 야기됨을 관찰하여 이 기전을 뒷받침하였다. ${ }^{24)}$ 이러한 손상은 바이러스 감염이 호 전된 이후에도 오랫동안 지속되며, 경우에 따라서 영구적으로 지속될 수 있다.

일차적인 치료 방법으로, 기도 과민반응을 줄이기 위해 알 레르기나 역류 질환과 같은 자극 요인을 없애는 것이 중요하 다. 보조적인 요법으로 알레르기나 인후두 역류질환의 약을 처방하기도 하며, 이러한 치료에도 반응을 하지 않는 경우 
dextromethorphan이나 코데인과 같은 진해제가 도움이 될 수 있다. 또한 트라마돌은 약한 마약성 약제로 코데인에 비 해 강한 진해 역할을 하여 효과적으로 사용할 수 있다. ${ }^{25)}$ 효 과적인 증상 호전을 위해서 gabapentin을 사용하는 것 또한 도움이 될 수 있다. ${ }^{26}$

\section{다른 폐의 질환}

다양한 폐나 심장의 상태가 만성 기침의 원인이 될 수 있으 며, 그 중 만성 기관지염이 가장 흔하다. ${ }^{27)}$ 일반적으로 만성 기관지염은 흡연으로 인해 발생하게 되며, ${ }^{28)}$ 섬모화된 세포 가 없어지면서 상피 세포의 배상 세포가 증가하면서 발생한 다. 기침은 보통 30,40 대에 흡연을 시작하면서 발생하여 점 차 심해지며, 일차적인 치료는 흡연을 끊는 것으로, 그렇다고 해서 곧바로 증상이 호전되지 않을 수도 있다. 항생제는 급 성 악화기에는 도움이 될 수 있다.

또한 우리나라는 결핵의 유병률이 높은 곳이므로, 흥부 단 순촬영, 객담의 acid-fast bacteria 염색 및 $\mathrm{PCR}$ 을 통하여 결 핵의 가능성에 대해 확인할 필요가 있다.

\section{유육종(Sarcoidosis)}

유육종은 $90 \%$ 이상에서 폐를 침범하는 전신 질환의 일종 으로, 가장 흔하게 나타나는 증상 중의 하나가 만성 기침이 다. ${ }^{29)}$ 보통 흥부 단순촬영을 통해 진단되며 보통 병리적으로 비괴사성 육아종이 발견되면서 진단된다. 전신 스테로이드가 일차적인 치료법이며 어떤 경우에는 methotrexate와 같은 세 포 독성 치료가 효과적이기도 한다.

기관지성 암 또한 만성 기침으로 시작될 수 있으며, 치명적 인 결과를 보일 수 있으므로 특히 흡연자에서 중요하다. ${ }^{30}$ 불 행하게도 처음 진단이 될 당시에 이미 많이 진행된 상태일 수 있으며 예후도 좋지 않다.

\section{심리적 기침}

심리적인 기침의 대다수가 소아와 청소년기 환자에서 일어 나나 성인에서도 나타날 수 있다. 이전에 진술된 많은 원인들 이 모두 배제된 이후 의심할 수 있는 것으로 만성 기침과 불 안증과의 관계는 잘 알려져 있다. ${ }^{31)}$ 하지만 심리적인 원인만 이 만성 기침의 원인이라고 말하기에는 불명확한 점이 많다.

역설성 성대운동(paradoxical vocal fold movement)은 흡 기 동안에 비정상적으로 성대가 내전을 하는 것으로, 일반적 으로 치료에 불응하며 천식과 같이 상기도가 막히는 듯한 증상을 보이기도 하며, 어떤 경우에는 기관 절개술이나 기관 삽관까지 필요할 정도로 심각한 증상을 보이기도 한다. 우리 나라에서는 매우 드물게 증례 보고된 바 있는 질환으로, ${ }^{32,33)}$
역설성 성대운동이 있는 환자들에게 보호 반응으로써 성문 폐쇄 반응이 증가되어 있어, 만성 기침과의 연관성을 보인다 는 보고가 있다. ${ }^{34)}$ 이러한 역설성 성대운동은 전형적으로 젊 은 여성에서 나타나며, 심리적인 원인이 연관되어 있어 전환 장애의 일환으로 생각되기도 한다. 스트레스와 심리적인 원 인, 기능적인 호흡 및 음성의 이상, 다른 전신 질환이나 흡인 성 물질 등에 의해 유발될 수 있으며, 특히 GERD와 연관이 있으며 다른 외부 자극 물질에 대해 더욱 민감하게 반응을 보인다. ${ }^{35,36)}$ 만약 심리적인 기침이 의심된다면 심리 치료, 완화 치료, 호흡 운동, 음성 치료와 같은 다각적인 치료가 진행되어 야 하며 심리적인 치료와 언어 치료사의 진료가 필요하다. 37,38$)$

\section{기 타}

최근 기침이 수면무호흡증의 다른 발현 양상일 수 있다고 주장하는 연구가 있었다. ${ }^{39}$ 수면무호흡증이 기침을 발생시키 는 기전은 불명확하나, 수면 시 무호흡이 일어나는 동안에 횡 경막 주변의 압력이 증가하면서 하부 식도 조임근의 기능을 낮추어 위식도 역류를 조장할 수 있다는 가설과, 무호흡과 코 골이로 인한 상기도의 상피층의 손상과 연관되어 기침이 발생 한다는 가설이 있다. 실제 수면무호흡과 기침이 있던 환자군에 서 지속적 양압 치료와 같은 수면무호흡의 치료만으로 기침 증상의 확연한 호전을 보였다는 보고가 있었으나, ${ }^{39)}$ 추후 더 많은 연구를 통해 그 관련성을 밝혀낼 필요가 있다. 그 외 편 도의 비대와 관련하여 만성 기침이 발생하였다는 보고도 있 으며, 이러한 환자에서 편도선 절제술을 시행 후 기침의 호전 을 보이기도 하였다. ${ }^{40)}$

실제 외래를 찾아오는 환자의 최대 $42 \%$ 까지가 원인이 밝 혀지지 않는 경우가 있어, 이들을 원인 모를 만성 기침(unexplained cough, idiopathic chronic cough, ICC)으로 분류 할 수 있다. ICC의 전형적인 환자 유형은 대부분 폐경 근처의 여성으로, 상기도 감염이 선행되는 경우가 많다. 드물게는 이 러한 ICC 환자들에서 정상인에 비해 자가면역 질환과의 관 련성이 높다는 보고도 있으며, 특히 갑상선 기능저하증과 높 은 연관성을 보여서 이 환자군에서 기도의 염증 및 기침 반 응의 민감도가 높아진다는 보고가 있다. ICC의 많은 환자들 에서 기침의 과민반응, 기도의 과잉반응성, 그리고 기도의 염 증을 그 원인으로 설명할 수 있으며, 이러한 시각의 변화는 기침을 그 자체의 질환으로 인식하여 기도의 신경의 이상이나 진해제 치료의 새로운 목표를 세우는 등에 대한 연구를 진행 하는 데 도움이 될 것으로 생각된다.

\section{진해제 치료}

특정한 원인이 밝혀지지 않은 만성 기침에 대해 진해제를 
통한 증상 치료를 시행하게 된다. 상기도 감염이 발생하였을 때 일차적으로 1 세대 항히스타민제와 비충혈제를 사용하게 되며 흡인성 항콜린제(ipratropium bromide), 그리고 말초성 진해제가 단기간 증상을 조절하는 데 사용할 수 있다. 말초성 진해제로는 levo-dropropizine과 moquisteine 같은 약물을 사용하며 중추성 진해제로 코데인, dextromethorphan 등을 사용한다. 또한 진해제를 직접적, 그리고 간접적인 진해제로 나눌 수 있는데 모르핀은 직접적으로 기침 반응에 관여하며, ICC 환자들에게 사용 시 효과가 밝혀진 바 있고, 말초성 기침 반응의 과민성에는 반응하지 않는다. ${ }^{41)}$ 코데인 또한 직접적으 로 반응을 보이나 무작위 연구를 통해 그 효험을 증명된 바 없으며, 바이러스성 감염 이후 혹은 만성 폐쇄성 폐질환 환 자의 기침에서 위약에 비해 효과가 없었던 것으로 밝혀진 바 있다. ${ }^{42,43)}$ 간접적으로 작용하는 약물에는 leukotriene 길항제 인 zafirlukast 등으로 기침의 과민반응을 억제하는 역할을 하며 기침성 천식에 사용할 수 있다. ${ }^{12)}$ Erythromycin은 중성 구의 염증 반응을 억제하나 ICC 환자에서는 효과적이지 않 다. ${ }^{44)}$ 그러므로 추후 진해제는 직접적인 경로, 특히 기도의 신 경 쪽에 집중하여 발전되어야 할 것으로 생각된다. 그 외 언 어나 발성 프로그램을 통해 기침을 억제하고 성대 기능 부전 을 줄이며 음성을 호전시키는 데 효과적이라는 보고가 있으 며, 이러한 치료는 설명되지 않는 만성 기침에 권고할 수 있 다. ${ }^{44)}$ 불행하게도 현재 효과적이라고 알려져 있는 진해제는 없으며 진해제는 기침을 하려는 충동이나 인후두의 불편감 을 없애지만, 보호성 기침을 억제하지 않도록 만들어져야 한 다. 이러한 작용에 대해 가능한 것으로 TRPV1이나 TRPA1 길 항제가 C-fiber의 기능을 변화시켜 말초성 감작을 억제할 수 있으며, gamma-aminobutyric acid agonist 혹은 N-methylD-aspartate antagonist는 중추성 감작에 작용할 수 있을 것 으로 생각된다.

\section{결 론}

만성 기침으로 내원하는 환자의 수는 많으나, 그 중 정확한 진단을 내리지 못하고 효과적인 치료를 하지 못하는 경우가 발생한다. 상기도 기침증후군(UACS), 기침성 천식(CVA), 위 식도 역류질환(GERD) 등이 성인의 만성 기침의 대부분 원인 이 되며, $\mathrm{ACE}$ 억제제 투약을 비롯한 병력, 흥부와 부비강 단 순촬영 검사, 알레르기 반응 검사, 폐기능 검사 등으로 감별 진단을 할 수 있다.

가장 흔한 원인의 대부분이 이비인후과 의사가 검진하여 진단을 내릴 수 있는 질병과 관련이 있다. 특히 이러한 검사 가 정상인 경우는 거의 대부분 위식도 역류와 관련이 있다고
볼 수 있으므로, 이비인후과 의사로서 다른 가능한 이비인후 과 질환과의 감별 진단을 시행하고, 위식도 역류질환과 관련 된 기침의 병태생리기전을 잘 이해하고 적절한 투약과 생활 습관 조절을 적용하여 효과적인 만성 기침의 치료를 행할 수 있어야 하겠다. ICC의 경우 많은 환자들에서 기침의 과민반 응, 기도의 과잉반응성과 관련이 있을 것으로 생각되며, 이러 한 생리학적 기전을 잘 이해하여 기도의 신경의 이상이나 진해 제 치료의 새로운 목표를 세우는 등에 대한 연구를 진행하는 것이 필요할 것으로 생각된다.

\section{Acknowledgments}

This work was supported by Biomedical Research Institute grant, Kyungpook National University Hospital (2014).

\section{REFERENCES}

1) Morice AH, McGarvey L, Pavord I; British Thoracic Society Cough Guideline Group. Recommendations for the management of cough in adults. Thorax 2006;61 Suppl 1:i1-24.

2) Pratter MR, Brightling CE, Boulet LP, Irwin RS. An empiric integrative approach to the management of cough: ACCP evidencebased clinical practice guidelines. Chest 2006;129(1 Suppl):222S$31 \mathrm{~S}$.

3) Morice AH, Fontana GA, Sovijarvi AR, Pistolesi M, Chung KF, Widdicombe $\mathrm{J}$, et al. The diagnosis and management of chronic cough. Eur Respir J 2004;24(3):481-92.

4) Irwin RS, Curley FJ, French CL. Chronic cough. The spectrum and frequency of causes, key components of the diagnostic evaluation, and outcome of specific therapy. Am Rev Respir Dis 1990;141(3): 640-7.

5) Irwin RS, Baumann MH, Bolser DC, Boulet LP, Braman SS, Brightling CE, et al. Diagnosis and management of cough executive summary: ACCP evidence-based clinical practice guidelines. Chest 2006;129(1 Suppl):1S-23S.

6) Berry MA, Hargadon B, McKenna S, Shaw D, Green RH, Brightling $\mathrm{CE}$, et al. Observational study of the natural history of eosinophilic bronchitis. Clin Exp Allergy 2005;35(5):598-601.

7) Gibson GR. Enalapril-induced cough. Arch Intern Med 1989;149 (12):2701-3.

8) Canning BJ. Anatomy and neurophysiology of the cough reflex: ACCP evidence-based clinical practice guidelines. Chest 2006;129 (1 Suppl):33S-47S.

9) Canning BJ, Chou YL. Cough sensors. I. Physiological and pharmacological properties of the afferent nerves regulating cough. Handb Exp Pharmacol 2009;(187):23-47.

10) Mazzone SB. Sensory regulation of the cough reflex. Pulm Pharmacol Ther 2004;17(6):361-8.

11) Chung KF, Widdicombe JG. Cough: setting the scene. Handb Exp Pharmacol 2009;(187):1-21

12) Dicpinigaitis PV, Grimm DR, Lesser M. Cough reflex sensitivity in subjects with cervical spinal cord injury. Am J Respir Crit Care Med 1999;159(5 Pt 1):1660-2.

13) Groneberg DA, Niimi A, Dinh QT, Cosio B, Hew M, Fischer A, et al. Increased expression of transient receptor potential vanilloid-1 in airway nerves of chronic cough. Am J Respir Crit Care Med 2004; 170(12):1276-80.

14) Young EC, Brammer C, Owen E, Brown N, Lowe J, Johnson C, et al. The effect of mindfulness meditation on cough reflex sensitivity. Thorax 2009;64(11):993-8.

15) Birring SS, Parker D, Brightling CE, Bradding P, Wardlaw AJ, 
Pavord ID. Induced sputum inflammatory mediator concentrations in chronic cough. Am J Respir Crit Care Med 2004;169(1):15-9.

16) Harding SM, Richter JE. The role of gastroesophageal reflux in chronic cough and asthma. Chest 1997;111(5):1389-402.

17) Schnatz PF, Castell JA, Castell DO. Pulmonary symptoms associated with gastroesophageal reflux: use of ambulatory $\mathrm{pH}$ monitoring to diagnose and to direct therapy. Am J Gastroenterol 1996;91(9):1715-8.

18) Irwin RS, Zawacki JK, Curley FJ, French CL, Hoffman PJ. Chronic cough as the sole presenting manifestation of gastroesophageal reflux. Am Rev Respir Dis 1989;140(5):1294-300.

19) Ing AJ, Ngu MC, Breslin AB. Pathogenesis of chronic persistent cough associated with gastroesophageal reflux. Am J Respir Crit Care Med 1994;149(1):160-7.

20) Faruqi S, Molyneux ID, Fathi H, Wright C, Thompson R, Morice AH. Chronic cough and esomeprazole: a double-blind placebocontrolled parallel study. Respirology 2011;16(7):1150-6.

21) Pratter MR, Bartter T, Akers S, DuBois J. An algorithmic approach to chronic cough. Ann Intern Med 1993;119(10):977-83.

22) O'Hara J, Jones NS. "Post-nasal drip syndrome": most patients with purulent nasal secretions do not complain of chronic cough. Rhinology 2006;44(4):270-3.

23) Overlack A. ACE inhibitor-induced cough and bronchospasm. Incidence, mechanisms and management. Drug Saf 1996;15(1):72-8.

24) Jacoby DB, Fryer AD. Interaction of viral infections with muscarinic receptors. Clin Exp Allergy 1999;29 Suppl 2:59-64.

25) Szekely SM, Vickers MD. A comparison of the effects of codeine and tramadol on laryngeal reactivity. Eur J Anaesthesiol 1992;9(2): 111-20.

26) Lee B, Woo P. Chronic cough as a sign of laryngeal sensory neuropathy: diagnosis and treatment. Ann Otol Rhinol Laryngol 2005;114(4):253-7.

27) Grossman RF. Guidelines for the treatment of acute exacerbations of chronic bronchitis. Chest 1997;112(6 Suppl):310S-3S.

28) Wilson R, Wilson CB. Defining subsets of patients with chronic bronchitis. Chest 1997;112(6 Suppl):303S-9S.

29) Baughman RP. Pulmonary sarcoidosis. Clin Chest Med 2004;25 (3):521-30, vi.

30) Adjei AA, Marks RS, Bonner JA. Current guidelines for the management of small cell lung cancer. Mayo Clin Proc 1999;74(8): 809-16.

31) Carney IK, Gibson PG, Murree-Allen K, Saltos N, Olson LG, Hensley MJ. A systematic evaluation of mechanisms in chronic cough. Am J Respir Crit Care Med 1997;156(1):211-6.

32) Ahn CM, Lee SH, Choi JH. Two cases of paradoxical vocal fold movement. Korean J Otolaryngol-Head Neck Surg 2001;44(12): 1355-7.

33) Baek CH, Jung YS, Yoon YS, Hong BS. A case of paradoxical vocal fold motion with dyspnea and stridor. Korean J Otolaryngol-Head Neck Surg 2002;45(2):195-9.

34) Altman KW, Simpson CB, Amin MR, Abaza M, Balkissoon R, Casiano RR. Cough and paradoxical vocal fold motion. Otolaryngol Head Neck Surg 2002;127(6):501-11.

35) Morrison M, Rammage L, Emami AJ. The irritable larynx syndrome. J Voice 1999;13(3):447-55.

36) Perkner JJ, Fennelly KP, Balkissoon R, Bartelson BB, Ruttenber AJ, Wood RP 2nd, et al. Irritant-associated vocal cord dysfunction. J Occup Environ Med 1998;40(2):136-43.

37) Riegel B, Warmoth JE, Middaugh SJ, Kee WG, Nicholson LC, Melton DM, et al. Psychogenic cough treated with biofeedback and psychotherapy. A review and case report. Am J Phys Med Rehabil 1995;74(2):155-8

38) Blager FB, Gay ML, Wood RP. Voice therapy techniques adapted to treatment of habit cough: a pilot study. J Commun Disord 1988;21(5): 393-400.

39) Birring SS, Ing AJ, Chan K, Cossa G, Matos S, Morgan MD, et al. Obstructive sleep apnoea: a cause of chronic cough. Cough 2007;3:7.

40) Birring SS, Passant C, Patel RB, Prudon B, Murty GE, Pavord ID. Chronic tonsillar enlargement and cough: preliminary evidence of a novel and treatable cause of chronic cough. Eur Respir J 2004;23 (2):199-201

41) Morice AH, Menon MS, Mulrennan SA, Everett CF, Wright C, Jackson J, et al. Opiate therapy in chronic cough. Am J Respir Crit Care Med 2007;175(4):312-5.

42) Smith J, Owen E, Earis J, Woodcock A. Effect of codeine on objective measurement of cough in chronic obstructive pulmonary disease. $\mathrm{J}$ Allergy Clin Immunol 2006;117(4):831-5.

43) Woodcock A, McLeod RL, Sadeh J, Smith JA. The efficacy of a NOP1 agonist (SCH486757) in subacute cough. Lung 2010;188 Suppl 1:S47-52.

44) Vertigan AE, Theodoros DG, Gibson PG, Winkworth AL. Efficacy of speech pathology management for chronic cough: a randomised placebo controlled trial of treatment efficacy. Thorax 2006;61(12): $1065-9$. 